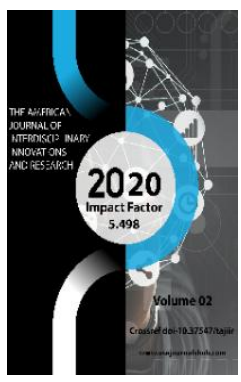

Journal Website: http://usajournalshub.c om/index,php/tajiir

Copyright: Original content from this work may be used under the terms of the creative commons attributes 4.0 licence.

\section{R\&D Expenditure As A Factor In The Development Of The Economy Of Knowledge}

\author{
Khasankhonova Nodira Isametdinovna \\ Senior Lecturer, Department Of Economics, Tashkent Financial Institute,, Uzbekistan \\ Abdulkhalilova Saboxat Naimovna \\ Senior Lecturer, Department Of Economics, Tashkent Financial Institute Index100000, \\ Uzbekistan, Tashkent City, A.Temur Street 60a, Uzbekistan
}

\title{
ABSTRACT
}

Creating conditions for R\&D in the post-industrial type of development is an extremely urgent issue. With its scientific potential, the economy will be in a significant advanced position compared to developing countries. The article examines the current state of research in the field of the economy of knowledge and innovation, reveals the factors of accelerated development of the knowledge economy. Separately, the requirements are disclosed that make it possible to create systemic prerequisites for the formation of a knowledge economy and an innovation environment.

\section{KEYWORDS}

Research, R\&D, innovation, science, human capital, knowledge economy

\section{INTRODUCTION}

$R \& D$ - research and development work - a set of scientific and design work, the purpose of which is to acquire new knowledge or create a new product / technology. R\&D expenditures (Research and Development and Development Works) are an important indicator of the innovative activity of a state, company or enterprise. However, R\&D expenditures are recognized whether or not they are positive.

To carry out $R \& D$, it is required to allocate budgets (funding) for R\&D, as well as the availability of highly qualified personnel, whose tasks include the implementation of the $R \& D$ complex. R\&D activities should be carried out in accordance with a clear action plan, broken down into stages.

Very often, R\&D work and services (Research and Development and Experimental Design Works) are accompanied by the following types of work:

- Scientific Research Work (R\&D),

- Experimental Design Work (ROC),

- Technological Work (TR), 
- other research work aimed at obtaining and using new knowledge.

The main difference between research and development (R\&D) and related activities at the enterprise is the presence of an element of novelty in the development. In this case, we are talking precisely about the creation (development) of a new type of technology, products, services, etc.

Spending on science is considered to be a measure of the maturity of an economy. For commercial companies, many believe that the more investment in new developments, the higher the return. It is not that simple. Statistics show that there is no direct relationship, and investing in R\&D should be thoughtful and rational.

The Main Findings and Results

In the knowledge economy, it is an important condition for activating human capital and creating incentives to attract talented young specialists to scientific activities. This is feasible, first of all, at the existing scientific sites of universities and other scientific and educational organizations. Scientific research must have a clear connection with innovative trends in the development of the economy. In particular, scientific activity should be organized in such a way as to directly determine the level of innovative activity of entrepreneurship.

In more developed and wealthy countries, due to the rational development of the knowledge economy, there is a high level of income, a high level of provided medicine and a strong educational system. This level sets the goal for each developing country. And if you look at it in detail, you can see the following: formed institutions, infrastructure, constantly entering innovations in any field of activity, a stable financial position. And also the most important thing is a rational direction economically on the right track.

A.S. Shurupova [1. 14-15] notes that the role of intellectual and information resources in the world experience in the development of the knowledge economy is high. She says that the development of the knowledge economy in the United States is associated with high levels of R\&D spending. In recent years, many countries have paid particular attention to the development of areas such as ICT and biotechnology (or nanotechnology), which require active scientific and knowledge intervention. However, energy technology remains a priority in Japan, agriculture in Canada, space exploration in France, and industrial technology in Canada, Germany, Italy and South Korea. In the second half of the 90 s of the twentieth century, in many countries, interest in improving the procedures for scientific and technical forecasting, selection and assessment of priorities for scientific and technological development increased. This is due to the fact that the role of research in ensuring economic growth is increasing, and there is a desire to more effectively use the limited public resources allocated to research and development.

In fact, if we consider the costs of R\&D, we get the following data (Table 1): 
Table 1

R\&D expenditures of countries of the world (percent of GDP) [2]

\begin{tabular}{|c|c|c|c|c|c|c|}
\hline № & The state & $\mathbf{2 0 1 4}$ year & $\mathbf{2 0 1 5}$ year & $\mathbf{2 0 1 6}$ year & $\mathbf{2 0 1 7}$ year & $\mathbf{2 0 1 8}$ year \\
\hline 1 & Israel & 4,2 & 4,3 & 4,5 & 4,8 & 5 \\
\hline 2 & South Korea & 4,3 & 4,2 & 4,2 & 4,6 & 4,8 \\
\hline 3 & Sweden & 3,1 & 3,3 & 3,3 & 3,4 & 3,3 \\
\hline 4 & Japan & 3,4 & 3,3 & 3,2 & 3,2 & 3,3 \\
\hline 5 & Austria & 3,1 & 3,0 & 3,1 & 3,1 & 3,2 \\
\hline 6 & German & 2,9 & 2,9 & 2,9 & 2,9 & 3,1 \\
\hline 7 & Denmark & 2,9 & 3,1 & 3,1 & 3,0 & 3,1 \\
\hline 8 & USA & 2,7 & 2,7 & 2,8 & 2,8 & 2,8 \\
\hline 9 & Belgium & 2,4 & 2,5 & 2,6 & 2,7 & 2,8 \\
\hline 10 & Finland & 3,2 & 2,9 & 2,7 & 2,8 & 2,8 \\
\hline 30 & Russian & 1,1 & 1,1 & 1,1 & 1,1 & 1,0 \\
& Federation & & & & & \\
\hline 62 & Uzbekistan & 0,2 & 0,2 & 0,2 & 0,2 & 0,1 \\
\hline 64 & Kazakhstan & 0,2 & 0,2 & 0,1 & 0,1 & 0,1 \\
\hline
\end{tabular}

From the data in the table, we know that the country that spends the most on GDP is Israel. If we analyze this country, we see that research in universities is second only to the United States (scientists are also known as Nobel Prize winners), human capital holds a special place, and the level of industrial integration with research is very high. South Korea, which is ranked second, also has a high level of investment in knowledge, and ICT costs are also significant. It should be noted that the focus on ICT is particularly strong in this country. In general, the knowledge economy is formed by spending on R\&D over the past 10 years for a dozen countries in the table. They are characterized by the production of scientific knowledge, technological innovation, the integration of business and higher education, and high spending on innovative goods and services.

This is due to the fact that in most of the countries of the world that spend on R\&D, the knowledge economy is moving in the right 
direction, and scientific research is the driving force of the economy.

Talking about science in an ideological regime (why the state allocates less to scientists than to athletes) is unproductive. In most countries, the corporate sector bears the main burden of spending on new developments. It makes no sense to calculate the average percentage of investments in R\&D in business, in each industry the need for innovations and the cost of their serial production are different.

The concept of the knowledge economy was introduced in developed countries thanks to the involvement of highly potential specialists in research. According to the International Intellectual Property Organization, 16\% of China's population has applied for a patent for digital communications, $12 \%$ in the United States for computer technology, $11.2 \%$ for technical equipment in Japan and $10.7 \%$ for a car in Germany [3]. Today, these patents are world leaders in the application of sciencebased innovations in various sectors of the economy. For example, in 2019, Huawai Techlogies Co., a digital communications organization in China, received 4,411 [3] international scientific development patents. This shows how developed the knowledge economy is in this country.
Today, innovation is seen as one of the main sources of economic development. Innovative resources are among the most important reproductive and stimulating resources of the national economy. In the knowledge economy, modern innovations play a dominant and decisive role in production; they become an important factor in competition with the world, in the development of research and development, and intellectual capital.

The rapid development of various spheres of society and the state requires reforms based on modern innovative ideas, developments and technologies that provide a fast and highquality path for our country to become one of the leaders of world civilization.

The network of research and design organizations, in general, scientific and methodological support for the activities of enterprises representing innovative business, plays an important role in increasing the efficiency of innovation processes. Knowledge, intellectual property, intellectual assets, intellectual capital and ultimately innovative entrepreneurship play a key role in this context (Figure 3). This chain is built in such a way that when a part is broken, all processes collapse on a massive scale, and the economy loses its connection with research.

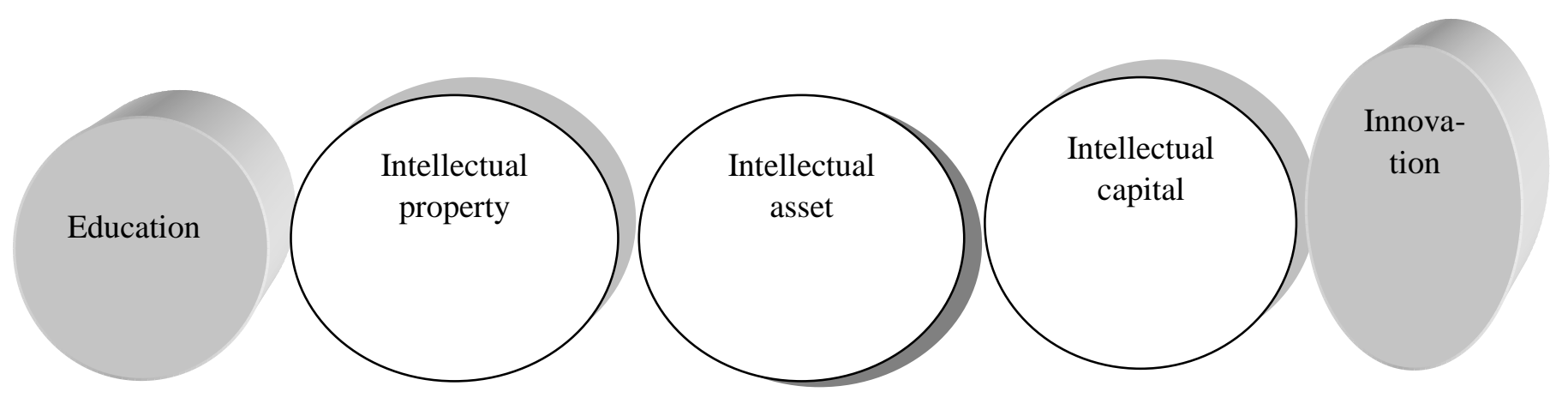


3-figure. A theoretical look at the process of transforming knowledge into innovation. In this chain, we can describe a linear model of knowledge transformation through the Institute of Intellectual Property (in our country, this is an intellectual property agency) as follows: the generated knowledge is taken into account by a research organization and becomes an intellectual asset of an economic entity; at the next stage, they are expressed in the form of capital of intellectual assets used in the innovation process; the use of intellectual capital in the production process leads to innovation. Consequently, the transformation of knowledge into intellectual capital (incomegenerating capital) leads to the emergence of innovative entrepreneurship in the economy.

According to A.S. Murtazin [4. 107-107], intellectual capital at the micro level is capital formed from knowledge, skills, production experience, personnel qualifications, as well as intangible assets, including software, patents, databases, trademarks, which are effectively used to generate profit (economic benefit). ... At the macro level, intellectual capital is human capital and part of the structural intangible capital of a particular country. At the macro level of intellectual capital: a part of the population with high ideas and postgraduate education, using new ideas, creative samples, certain elements of intellectual abilities, as well as a special category of the economically active population (entrepreneurs engaged in real production and innovation). included). Intellectual capital at the macro level includes systems for collecting and storing knowledge and data (databases, media, libraries, communications), knowledge production systems (various research organizations, design bureaus, scientific departments of companies, etc.), Complex training (general, secondary, higher and postgraduate education), as well as the institutional structure (a favorable environment for the production and free transfer of knowledge, state policy in the field of protecting the scientific potential of the country and the legal space for increasing the intellectual capital of the country's economy).

According to the State Committee on Sustainable Development Statistics, the number of surveys per million population in Uzbekistan and the cost of research and development are as follows. (table 2).

table 2

Costs for R\&D and the dynamics of the number of researchers per 1 million population [5]

\begin{tabular}{|l|c|c|c|c|c|}
\hline Indicators & $2014 \mathrm{y}$ & $2015 \mathrm{y}$ & $2016 \mathrm{y}$ & $2017 \mathrm{y}$ & $2018 \mathrm{y}$ \\
\hline $\begin{array}{l}\text { R \& D expenditure as\% } \\
\text { of GDP }\end{array}$ & 0,16 & 0,17 & 0,18 & 0,16 & 0,1 \\
\hline $\begin{array}{l}\text { The number of } \\
\text { researchers (in full } \\
\text { employment equivalent) } \\
\text { per 1 million population }\end{array}$ & 492 & 487 & 495 & 485 & 470 \\
\hline
\end{tabular}


Analyzing the data in Table 2, we can say that the number of researchers in the cost of research and development $(R \& D)$ increased in 2016, since it was during this period that Uzbekistan again switched to a two-tier system of doctoral and doctoral studies. This change affected them by a small shift in cost and number of researchers. Of course, we need to analyze this situation. In developed countries, $R \& D$ costs are around $1.5-3 \%$ of
GDP, while in developing countries this figure is usually $0.4 \%$. So these numbers are normal. The Committee on Intellectual Property of the Republic of Uzbekistan is an organization that studies the practical application of the knowledge economy in Uzbekistan and the level of intellectual capital. According to him, the number of applications for inventions in Uzbekistan is growing from year to year. (table 3).

table 3

Number of applications for inventions in Uzbekistan [6]

\begin{tabular}{|c|c|c|c|c|c|c|}
\hline Indicators & $2013 \mathrm{y}$. & $2014 \mathrm{y}$. & $2015 \mathrm{y}$. & $\begin{array}{c}2016 \\
\mathrm{y} .\end{array}$ & $\begin{array}{c}2017 \\
\mathrm{y} .\end{array}$ & Total \\
\hline $\begin{array}{c}\text { Total number of } \\
\text { applications }\end{array}$ & 557 & 568 & 507 & 555 & 553 & 2740 \\
\hline National applicants & 299 & 345 & 288 & 353 & 357 & 1642 \\
\hline Foreign applicants & 258 & 223 & 219 & 202 & 196 & 1098 \\
\hline $\begin{array}{c}\text { Including under a patent } \\
\text { corporation agreement }\end{array}$ & 248 & 210 & 213 & 194 & 185 & 1050 \\
\hline
\end{tabular}

Analyzing Table 3, we see that the number of national applicants for inventions increases from year to year, accounting for $64.6 \%$ of the total number of applicants. This testifies to the courage and confidence of our domestic inventors in the face of tomorrow's economic growth. The annual registration of these inventions can be seen in the table below. (table 4). 
table 4

The dynamics of registration of inventions [6]

\begin{tabular}{|c|c|c|c|c|c|c|}
\hline Indicators & $2013 \mathrm{y}$. & $2014 \mathrm{y}$. & $2015 \mathrm{y}$. & $\begin{array}{c}2016 \\
\mathrm{y} .\end{array}$ & $\begin{array}{c}2017 \\
\mathrm{y} .\end{array}$ & Total \\
\hline $\begin{array}{c}\text { Total number of } \\
\text { applications }\end{array}$ & 184 & 179 & 153 & 166 & 205 & 887 \\
\hline National applicants & 105 & 106 & 94 & 102 & 144 & 551 \\
\hline Foreign applicants & 79 & 73 & 59 & 64 & 61 & 336 \\
\hline $\begin{array}{c}\text { Including under a } \\
\text { patent corporation } \\
\text { agreement }\end{array}$ & 72 & 70 & 56 & 62 & 58 & 255 \\
\hline
\end{tabular}

Based on the data in Table 4, it should be noted that in 2017 there was an increase of $23.5 \%$ compared to the previous year. It can be seen from them that there are $70.2 \%$ more inventions of domestic manufacturers.

In 2017, there were 107 utility models, 124 industrial designs, 2300 trademarks, 2254 computer programs and databases, 40 breeding achievements and 388 intellectual property rights[6].

Summing up the author's research, we note that for the development of the knowledge economy in the above-mentioned states, we emphasize that the implementation and fulfillment of the following requirements are necessary, which will form the basic conditions for innovative development, which is currently extremely weak.

First, it is an assessment of the real state of affairs with the implementation of innovations, determination of the actual results and their nature.

Secondly, the definition of the factors of growth of innovations in the areas that are relevant. Currently, this is mainly $R \& D$.
Third, the search for sources and reserves of $R \& D$ growth, determination of forms of development of science and practice in these areas.

Fourth, this is a separate study of the state of human capital, the search and selection of directions for its development.

And finally, fifthly, the formation of guidelines for growth in the presence of a connection between theoretical, scientific works on the one hand, and practical, applied, on the other hand.

\section{REFERENCES}

1. Shurupova A.S. Foreign experience in the formation of a knowledge-based economy and its adaptation to Russian conditions. Bulletin of TSU, issue 7 (75), 2009. -p.14-15

2. https://knoema.ru/atlas/topics/ Research and development / R\&D-expenditure / $R \& D$-expenditure in percent-to-GDP

3. https://www.wipo.int/edocs/infogdocs/en /ipfactsandfigures2019/ according to the World Intellectual Property Organization 
4. Murtazin A.S. Institutional foundations for the formation of the knowledge economy in Russia. Dissertation for the degree of candidate of economic sciences. Penza, 2015
5. www.stat.uz

6. Annual report of the Intellectual Property Agency of the Republic of Uzbekistan. Tashkent: 2017 